\title{
Dynamics of Rickettsia parkeri infection in domestic chickens
}

\section{Dinâmica da infecção por Rickettsia parkeri em galinhas domésticas}

\author{
Jonas Fernandes Maciel' ${ }^{1}$; Joice Magali Brustolin ${ }^{1}$; Felipe da Silva Krawczak²; \\ Marta Elena Machado Alves ${ }^{1}$; Felipe Lamberti Pivoto ${ }^{1}$; Jonas Moraes-Filho²; \\ Marcelo Bahia Labruna ${ }^{3}$; Maristela Lovato ${ }^{4}$; Fernanda Silveira Flores Vogel ${ }^{4}$; \\ Sônia de Avila Botton ${ }^{4}$; Luis Antônio Sangioni ${ }^{4 *}$
}

\begin{abstract}
The aim of the present study was to investigate experimental infections by Rickettsia parkeri in domestic chickens (Gallus gallus domesticus) and to determine the dynamics of antibody production during acute and chronic infection. The animals $(\mathrm{n}=64)$ were allocated into eight groups as follows: G1, inoculated intramuscularly (IM) with $2.5 \times 10^{5}$ Vero cells $(1 \mathrm{~mL})$ infected with $R$. parkeri; G2, inoculated IM with $5.0 \times 10^{5}$ Vero cells $(2 \mathrm{~mL})$ infected with $R$. parkeri; $\mathrm{G} 3$, received $1 \mathrm{~mL}$ of the inoculum subcutaneously (SC); G4, received $2 \mathrm{~mL}$ of inoculum SC; G5, received $1 \mathrm{~mL}$ of the inoculum intraperitoneally (IP); G6, injected with $2 \mathrm{~mL}$ of the inoculum IP; G7 and G8, received $1 \mathrm{~mL}$ and $2 \mathrm{~mL}$ of culture medium IM, respectively (negative control groups). All $R$. parkeri inocula were viable prior to inoculation in the birds. In order to assess the dynamics of antibody production in acute and chronic infection, sera of chickens were collected 3, 7, 14, and $21 \mathrm{~d}$ post infection (PI) and assessed using an immunofluorescence antibody test (IFAT). In addition, PCR ( $g l t A$ gene) was performed using fragments of spleen and lung from euthanized chickens to detect the replication of $R$. parkeri in tissues during the experimental period. Animals from the G4 and G3 groups exhibited the highest mean antibody titers, with maximum levels observed at 7 and $14 \mathrm{~d}$ PI, respectively. Conversely, G2, G4 and G6 exhibited higher mean antibody titers than G1, G3 and G5, respectively. Antibody titers were dose-dependent. Rickettsial DNA was not detected in either spleen or lung tissue. The present study demonstrated that birds seroconvert after being challenged by $R$. parkeri. However, there was no replication of the agent in the tissues analyzed and rickettsemia was not observed.
\end{abstract}

Key words: Gallus gallus domesticus, immunofluorescence antibody test, inoculation, polymerase chain reaction, spotted fever

\section{Resumo}

O objetivo deste estudo foi avaliar a infecção experimental por Rickettsia parkeri em galinhas domésticas (Gallus gallus domesticus) e investigar a dinâmica de anticorpos. Para tanto, foram utilizadas 64 galinhas criadas extensivamente divididas em oito grupos: G1 - inoculado com 2,5 x $10^{5}$ células Vero

\footnotetext{
${ }^{1}$ Discentes do Programa de Pós-Graduação em Medicina Veterinária, Universidade Federal de Santa Maria, UFSM, Santa Maria, RS, Brasil. E-mail: jonasfernandesmaciel@gmail.com; joicebrustolin@yahoo.com.br; marta.elenamachado@gmail.com; felipe. pivoto@gmail.com

2 Discentes do Programa de Pós-Graduação em Epidemiologia Experimental Aplicada às Zoonoses, Universidade de São Paulo, USP, São Paulo, SP, Brasil. E-mail: felipekvet@gmail.com; jonasmfilho@hotmail.com

3 Prof. Dr., Dept ${ }^{\circ}$ de Medicina Veterinária Preventiva e Saúde Animal, Faculdade de Medicina Veterinária e Zootecnia, Universidade de São Paulo, USP, São Paulo, SP, Brasil. E-mail: labruna@usp.br

${ }^{4}$ Profs. Drs., Dept ${ }^{\circ}$ de Medicina Veterinária Preventiva, DMVP, Universidade Federal de Santa Maria, UFSM, Santa Maria, RS, Brasil. E-mail: maristelalovato@gmail.com; fefevogel@gmail.com; sabott20@gmail.com; lasangioni@gmail.com

* Author for correspondence
} 
(1 ml) infectadas por R. parkeri via intramuscular (IM); G2 - 5,0 x 105 células Vero (2 ml) infectadas por R. parkeri via IM; G3 - $1 \mathrm{ml}$ do inóculo via subcutânea (SC); G4 - $2 \mathrm{ml}$ de inóculo via SC; G5 - 1 $\mathrm{ml}$ do inóculo via intraperitoneal (IP); G6 - 2 ml de inóculo via IP, e G7 e G8 - 1 e 2 ml de meio de cultivo de células Vero via IM, respectivamente representando os grupos controles negativos. Ressaltase que todos os inóculos de $R$. parkeri estavam viáveis no momento da inoculação. Os soros das aves foram coletados aos 3, 7, 14 e 21 dias pós-infecção (PI) e testadas por reação de imunofluorescência indireta (RIFI) para avaliar a dinâmica de anticorpos na infecção aguda e crônica. A identificação da multiplicação de $R$. parkeri nos tecidos, no mesmo período PI, foi realizada por PCR, para um fragmento do gene gltA, em amostras de baço e pulmão provenientes das galinhas eutanasiadas. As aves do G4 e G3 apresentaram as maiores médias de anticorpos obtendo os níveis mais elevados aos sete e 14 dias PI, respectivamente. G2, G4 e G6 apresentaram médias de anticorpos superiores comparados aos G1, G3 e G5 respectivamente, sendo considerada a infecção dose-dependente. Não foi detectado DNA rickettsial nos tecidos avaliados. No presente trabalho foi possível demonstrar que as aves soroconverteram mediante o desafio da inoculação por R. parkeri, todavia não houve a identificação do agente nos tecidos analisados, bem como a presença de rickettsemia.

Palavras-chave: Febre maculosa, Gallus gallus domesticus, inoculação, reação de imunofluorescência indireta, reação em cadeia da polimerase

\section{Introduction}

Rickettsia parkeri is an obligate intracellular bacterium that belongs to the spotted fever group (SFG) of rickettsia. Since 2004, this pathogen has been recognized as a cause of clinical human disease in the United States (PADDOCK et al., 2004). In South America, R. parkeri as the cause of human disease has only been confirmed in Uruguay and Argentina (CONTI-DÍAZ et al., 2009; ROMER et al., 2011). In Brazil, suspected cases of this rickettsiosis have been reported, especially in association with scabs. However, this has not been confirmed via the isolation of bacteria (SANGIONI et al., 2011; SILVA et al., 2011; SPOLIDORIO et al., 2010).

Rickettsia rickettsii, considered the most pathogenic species of the SFG, is found in different regions in Brazil. In several areas where spotted fever is endemic, other Rickettsia species have been identified in tick vectors (PHILIP; CASPER, 1981). For instance, $R$. parkeri has been detected in Amblyomma spp. in several South American countries, including Brazil, Uruguay, and Argentina (NAVA et al., 2008; SILVEIRA et al., 2007; VENZAL et al., 2004).

Birds and their role in the epidemiology of rickettsiosis have been studied worldwide. These studies have focused on the detection of SFG rickettsia in ticks parasitizing various birds living in distinct ecological niches (ELFVING et al., 2010; GRAHAM et al., 2010; HILDEBRANDT et al., 2010; OGRZEWALSKA et al., 2010).

R. rickettsii is the only species in which the experimental infection of birds, including domestic chickens, has been assessed (LUNDGREN et al., 1966). Studies on the prevalence of Rickettsia spp. in ticks parasitizing birds have been conducted in Brazil and other parts of the world (LUGARINI et al., 2015; OGRZEWALSKA et al., 2010). However, there is no information on the infection of domestic chickens with this bacterium.

Therefore, the aim of the present study was to experimentally infect domestic chickens with $R$. parkeri and to assess the dynamics of this infection to determine whether these birds could participate in the epidemiology of this rickettsiosis.

\section{Materials and Methods}

\section{Bacterial inoculum}

We used the AT24 strain of $R$. parkeri, isolated from a tick (Amblyomma triste) collected in Paulicéia, São Paulo State, Brazil (SILVEIRA et al., 2007). To isolate the pathogen, tissue from infected 
ticks was inoculated into Vero cells and maintained in cell culture flasks at $28{ }^{\circ} \mathrm{C}$. Infected cells were passaged three times in Vero cells.

The bacterial inoculum was prepared based on a protocol described by Horta et al. (2010), with modifications. The level of cellular infection was determined in each Vero cell passage using the Gimenez staining technique (GIMENEZ, 1964). From the last passage of infected Vero cells, the cellular monolayer was detached using a scraper and transferred to sterile Falcon ${ }^{\circledR}$ tubes $(50 \mathrm{~mL})$ containing culture medium Dulbecco's Modified Eagle Medium, (DMEM, Life Technologies Corporation, Carlsbad, CA). A final concentration of $2.5 \times 10^{5}$ infected cells $/ \mathrm{mL}$ was obtained.

\section{Experimental infection in domestic chickens}

Forty-five-day-old domestic chickens $(n=64)$ from a commercial breeding center were used in the present study. The animals were individually identified and maintained in an animal facility at Universidade Federal de Santa Maria (UFSM). All animals were maintained until they were 21 days (d) old and were fed with an antimicrobial-free diet. In addition, water was provided ad libitum and the animals were maintained under controlled air and temperature conditions throughout the experimental period. In order to confirm the absence of antiRickettsia antibodies in the animals, blood samples were taken and the sera were tested using the immunofluorescence antibody test (IFAT) before the beginning of the experiment. The animals were allocated into eight groups (G1-G8), each containing eight animals. Before the inoculations, the inoculum was vortexed to ensure the homogeneity of the suspension. Sterile disposable syringes and needles were used for this procedure. G1 and G2 were inoculated intramuscularly (IM) with $2.5 \times 10^{5}(1 \mathrm{~mL})$ and $5.0 \times 10^{5}(2 \mathrm{~mL})$ of Vero cells infected with $R$. parkeri, respectively. G3 and G4 were inoculated with $1 \mathrm{~mL}$ and $2 \mathrm{~mL}$ of the inoculum, respectively, subcutaneously (SC). G5 and $\mathrm{G} 6$ received $1 \mathrm{~mL}$ and $2 \mathrm{~mL}$ of the inoculum through the intraperitoneal (IP) route, respectively. Finally, the control groups (G7 and G8) received 1 $\mathrm{mL}$ and $2 \mathrm{~mL}$ of the non-infected culture medium (DMEM), respectively, through the IM route. All animals were clinically monitored throughout the study and the following parameters were assessed: temperature, dehydration, respiratory rate, appetite, and prostration.

\section{Serum collection}

Blood samples were collected by ulnar venipuncture the $3,7,14$, and $21 \mathrm{~d}$ post infection (PI). Afterwards, the samples were centrifuged and the sera obtained were stored at $-20{ }^{\circ} \mathrm{C}$ until serological analysis.

\section{Tissue samples}

In order to assess the replication of $R$. parkeri in animal tissues, two birds from each experimental group were euthanized by cervical dislocation method at 3, 7, 14, and $21 \mathrm{~d}$ PI. After the animals were euthanized, spleen $(\mathrm{n}=64)$ and lung $(\mathrm{n}=$ 64) fragments were collected for the detection of rickettsial DNA. All samples were submitted to DNA extraction, followed by PCR as described below.

\section{Immunofluorescence antibody test (IFAT)}

Serum samples were analyzed by IFAT using sensitized slides with crude antigen of $R$. parkeri (strain AT24), according to the method described by Horta et al. (2004). The sera were diluted with phosphate-buffered saline, starting with a dilution of 1:64. Next, $15 \mu \mathrm{L}$ of the diluted sera was deposited into each well of the IFAT slides, which were incubated in a humid chamber at $37^{\circ} \mathrm{C}$ for 30 $\min$. The slides were washed twice with washing solution and kept at room temperature $\left(25^{\circ} \mathrm{C}\right)$ for $10 \mathrm{~min}$. After drying, the slides were incubated at $37^{\circ} \mathrm{C}$ for $30 \mathrm{~min}$ with immunoglobulin anti-chicken 
conjugated $(1: 400)$ to fluorescein isothiocyanate (Sigma Diagnostics, St. Louis, Mo). Subsequently, the slides were washed and $0.2 \%$ Evans blue dye was added. Slides were then kept in a dark chamber for $10 \mathrm{~min}$. Finally, buffered glycerin was added and the slides were covered with a cover slip for microscopic analysis (Olympus BX60, Japan) at 40 $\times$ magnification. Positive and negative controls were included in each slide. Reactive sera were titrated to determine the levels of antibodies produced after infection.

\section{DNA extraction}

Genomic DNA from the spleen and lung fragments was extracted using the Wizard Genomic DNA Purification kit (Promega, Fitchburg, Wi, USA), following the manufacturer's instructions. The concentration of DNA was determined by spectrophotometry and the samples were stored at $-20{ }^{\circ} \mathrm{C}$ until molecular analysis.

\section{Polymerase chain reaction (PCR)}

The PCR reactions were performed using the primers CS-78 (5'-GCAAGTATCGGT GAGGATGTAAT-3') and CS-323 (5'-GCTTC CTTAAAATTCAATAAATCAGGAT-3'), which amplify a fragment of 401 base pairs (bp) of the citrate synthase gene $(g l t A)$, located in the mitochondrial matrix. This gene expresses an enzyme that participates in the first step of the citric acid cycle and is present in all species belonging to the genus Rickettsia (LABRUNA et al., 2004). If any sample was positive for the gltA gene, this would be submitted to a second PCR to identify species belonging to the SFG. The second reaction should be performed using the primers Rr190.70 (5'-ATGG CGAATATTTCTCCAAAA-3') and Rr190.602 (5'-AGTGCAGCATTCGCTCCCCCT-3'), which amplify a fragment of $530 \mathrm{bp}$ of the $190-\mathrm{kDa}$ protein gene ompA (REGNERY et al., 1991). The amplification reactions were performed in a final volume of $25 \mu \mathrm{L}$, containing 50 ng genomic DNA, $3 \mu \mathrm{M}$ of each primer (Invitrogen), $100 \mu \mathrm{M}$ dNTP (Invitrogen), $2 \mathrm{mM} \mathrm{MgCl}, 2.5 \mathrm{U}$ Taq DNA polymerase (Invitrogen), and $2.5 \mu \mathrm{L}$ enzyme buffer 10x. All reactions were performed in a thermocycler (T100TM Thermal Cycler, Bio-Rad) under the following conditions: 1 cycle at $95{ }^{\circ} \mathrm{C}$ for $3 \mathrm{~min}$; 40 cycles at $95{ }^{\circ} \mathrm{C}$ for $15 \mathrm{~s}, 48{ }^{\circ} \mathrm{C}$ for $30 \mathrm{~s}$, and 72 ${ }^{\circ} \mathrm{C}$ for $30 \mathrm{~s}$; and 1 cycle at $72{ }^{\circ} \mathrm{C}$ for $7 \mathrm{~min}$ and 4 ${ }^{\circ} \mathrm{C}$ for $2 \mathrm{~min}$. A negative (ultra pure water from the PCR grade) and positive (Vero cells infected with $R$. parkeri) element was included in each reaction. The amplification products were viewed under ultraviolet light following electrophoresis (120 volts for $30 \mathrm{~min})$ in an agarose gel (1\%) and stained with SYBR $^{\circledR}$ Safe DNA Gel Stain (Life Technologies Corporation, Carlsbad, CA, USA). In order to check the sensitivity of the molecular technique used in the present study, DNA extraction was performed from a pure culture of $R$. parkeri using the Wizard $^{\circledR}$ Genomic DNA Purification Kit (Promega, Fitchburg, WI, USA), following the manufacturer's instructions. The DNA concentration was measured by spectrophotometry (Picodrop Microliter UV/ Vis Spectrophotometer, Bulldog-Bio), followed by serial dilutions in ultra pure water (PCR grade) up to 1000 -fold. The samples were submitted to PCR as previously described (see above).

\section{Statistics}

The data were analyzed using analysis of variance (ANOVA), with group comparisons made using Tukey's test and a significance level of $95 \%$. The values of the titration were normalized using the formula " $\log _{10}(\mathrm{X}+10)$ ", with " $\mathrm{X}$ " being the titer of anti- $R$. parkeri antibodies. All analyses were performed using Graph Pad Prism $5^{\circledR}$ statistical software.

All procedures were performed in accordance with the Ethics Committee for Animal Experimentation (ECAE) of UFSM. This project was approved under protocol number 009/2011. 


\section{Results and Discussion}

After the experimental infection of domestic chickens with $R$. parkeri, differences in antibody titers were observed among the experimental groups and among individuals in each experimental group. Figures 1 and 2 present the mean antibody titers in each experimental group and the dynamics of the humoral immune response, respectively.

In G1, sero reactivity was not observed in the first $3 \mathrm{~d}$ PI. Seroconversion occurred on the $7^{\text {th }} \mathrm{d}$ PI, with antibody titers reaching 512 in one bird. After $14 \mathrm{~d}$ PI, the antibody titers decreased (maximum titer of 64) and then increased again after $21 \mathrm{~d}$ PI (maximum titer of 256). In G2 (5.0 x $10^{5}$ cells infected by $R$. parkeri IM), antibodies were detected $3 \mathrm{~d}$ PI (maximum titer of 512). After 7 and $14 \mathrm{~d}$ PI, antibody titers reached up to 1024 , followed by a reduction at $21 \mathrm{~d}$ PI (maximum titer of 256).In G3 (inoculated with $2.5 \times 10^{5} \mathrm{R}$. parkeri cells SC), low antibody titers (maximum titer of 64) were observed beginning $3 \mathrm{~d}$ PI in two chickens. After $7 \mathrm{~d}$
PI, titers ranging from 256 to 8192 were observed. The latter was the highest titer found among all birds in the present study. At $14 \mathrm{~d}$ PI, there was a decrease in antibody levels, with titers ranging from 256 to 4096. After $21 \mathrm{~d}$ PI, the antibody titers declined to 512. Animals in G4 seroconverted at 3 d PI (maximum titer of 64). At $7 \mathrm{~d}$ PI, higher levels of antibodies were found, with titers ranging from 512 to 8192 . At $14 \mathrm{~d}$ PI, the antibody titers remained elevated, reaching 8192, and a decrease was only observed at $21 \mathrm{~d}$ PI (maximum titer of 1024). In G5, the antibody titers ranged from 64 to 128 at $3 \mathrm{~d}$ PI. At $7 \mathrm{~d}$ PI, there was an increase in antibody levels up to 1024 . At $14 \mathrm{~d}$ PI, the levels decreased from 128 to 256 , and at $21 \mathrm{~d} \mathrm{PI}$, the birds were seronegative. Chickens in G6 exhibited serologic reactivity at all evaluated periods. At $3 \mathrm{~d}$ PI, titers ranging from 64 to 128 were detected. At 7 and $14 \mathrm{~d}$ PI, titers of up to 2048 were observed, and after $21 \mathrm{~d}$ PI, a reduction was observed, with titers ranging from 128 to 256 . In the negative control groups (G7 and G8), anti- $R$. parkeri antibodies were not detected.

Figure 1.Comparative analysis of the anti-R. parkeri antibody levels measured in chickens on day 3, 7, 14, and 21 after experimental infection (post infection, PI). (a) 3 days PI, (b) 7 days PI, (c) 14 days PI, and (d) 21 days PI. Data were normalized using the formula $\log (\mathrm{X}+10)$, in which $\mathrm{X}$ was the titration value obtained for each animal.

A

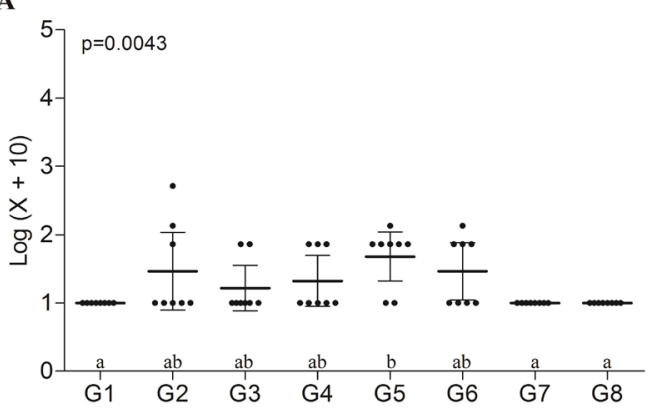

C

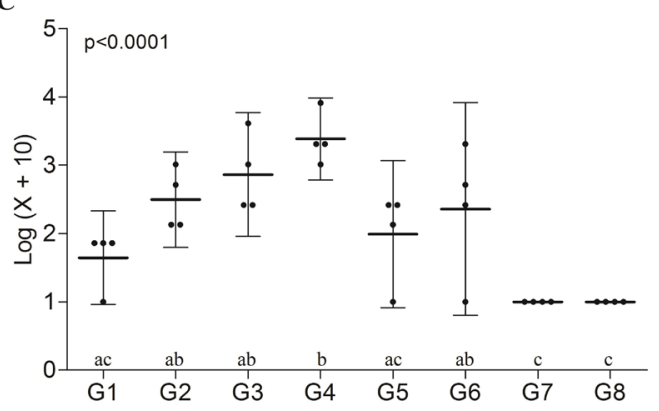

B

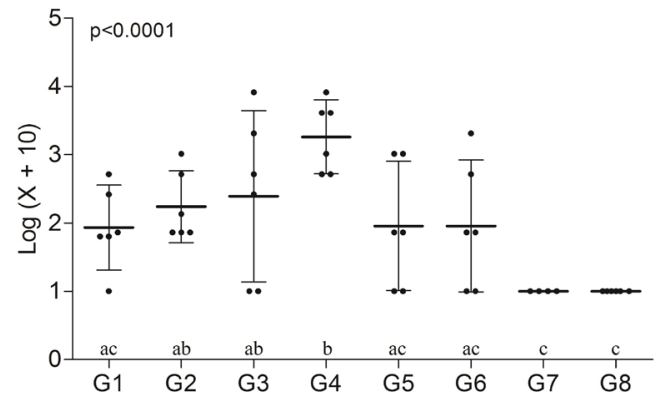

D

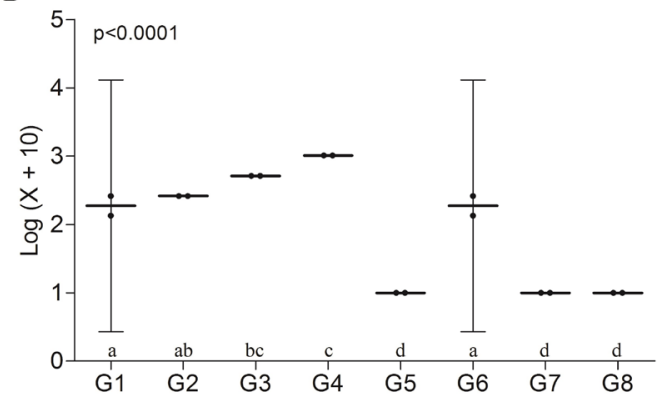


Throughout the experiment, no clinical abnormalities were observed in any of the birds studied.

The concentration of the DNA extracted from the $R$. parkeri culture was $81.5 \mathrm{ng} / \mu \mathrm{L}$. The conventional PCR technique used in the present study was able to detect DNA of this pathogen diluted 10-fold (8.15 ng/ $\mu \mathrm{L})$. Amplification of the 401-bp fragment corresponding to the gltA gene was not observed in any of the tissue samples analyzed by PCR. No PCR was carried out for the ompA gene because this gene is only found in rickettsia of the SFG (REGNERY et al., 1991).
In the present study, a dynamic humoral immune response was observed in all birds inoculated with $R$. parkeri. Antibody levels throughout the experimental period were higher in infected groups that received a higher dose of $R$. parkeri than in groups that received a lower dose by the same administration route (G1 and G2: IM; G3 and G4: SC; G5 and G6: IP) (Table 1 and Figure 2). In an in vitro study, Li and Walker (1992) demonstrated a dose-dependent relationship between rickettsia and host cells by flow cytometry. They observed that cell cultures exhibited a higher rate of infection by Rickettsia when cells were exposed to a greater amount of the pathogen.

Table 1. Mean and standard deviations for anti-R. parkeri antibody titers in each experimental group at four time points postinfection (PI) based on the immunofluorescence antibody test (IFAT).

\begin{tabular}{ccccc}
\hline Group & 3 days PI & 7 days PI & 14 days PI & 21 days PI \\
\hline G1 & $00 \pm 00.00$ & $160 \pm 193.06$ & $48 \pm 32.00$ & $192 \pm 90.51$ \\
G2 & $88 \pm 177.55$ & $309.33 \pm 391.22$ & $448 \pm 424.53$ & $256 \pm 0.00$ \\
G3 & $16 \pm 29.62$ & $1834.67 \pm 3207.33$ & $1408 \pm 1828.21$ & $512 \pm 0.00$ \\
G4 & $24 \pm 33.12$ & $3072 \pm 3020.37$ & $3328 \pm 3278.40$ & $1024 \pm 0.00$ \\
G5 & $56 \pm 41.02$ & $362.67 \pm 513.07$ & $160 \pm 122.55$ & $00 \pm 00.00$ \\
G6 & $40 \pm 47.62$ & $448 \pm 807.52$ & $704 \pm 920.06$ & $192 \pm 90.51$ \\
G7 & $00 \pm 00.00$ & $00 \pm 00.00$ & $00 \pm 00.00$ & $00 \pm 00.00$ \\
G8 & $00 \pm 00.00$ & $00 \pm 00.00$ & $00 \pm 00.00$ & $00 \pm 00.00$ \\
\hline
\end{tabular}

Figure 2. Dynamics of anti- $R$. parkeri antibody titers in experimentally infected domestic chickens, according to the mean titers obtained in the eight experimental groups. G1: animals infected by $2.5 \times 10^{5} R$. parkeri cells $(1 \mathrm{~mL}$ of inoculum) intramuscularly (IM). G2: animals infected by $5.0 \times 10^{5} R$. parkeri cells ( $2 \mathrm{~mL}$ of inoculum) IM. G3: animals infected by $1 \mathrm{~mL}$ of inoculum administered subcutaneously (SC). G4: animals infected by $2 \mathrm{~mL}$ of inoculum SC. G5: animals infected by $1 \mathrm{~mL}$ of inoculum administered intraperitoneally (IP). G6: animals infected by $2 \mathrm{~mL}$ of inoculum IP. G7 and G8: animals inoculated with $1 \mathrm{~mL}$ and $2 \mathrm{~mL}$ of culture medium IM, respectively (negative control groups).X axis: Days post infection. Y axis: Anti-R. parkeri antibody titer.

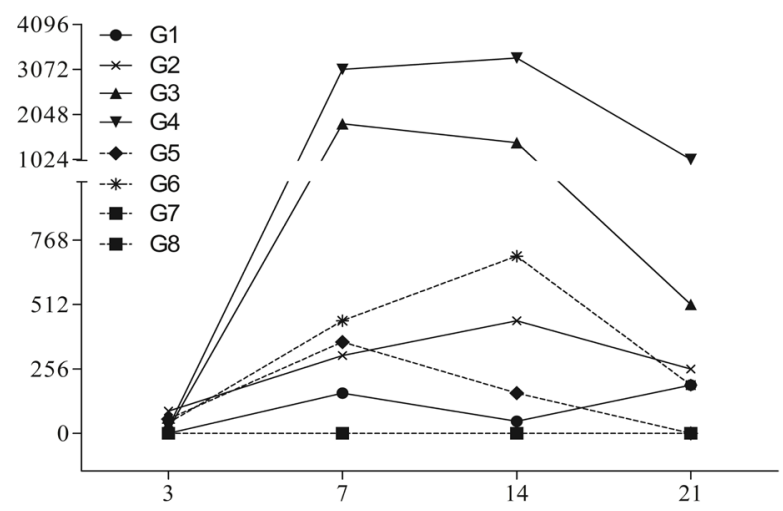


In the present study, despite the apparent doseresponse relationship in groups with the same administration via, the only statistically significant difference in antibody titer was between G5 and G6 at $21 \mathrm{~d} \mathrm{PI} \mathrm{(} 1 \mathrm{~mL}$ and $2 \mathrm{~mL}$ of inoculum, respectively) (Figure 1d). However, this in vivo study demonstrated dose-dependence, since animals challenged with a higher dose of $R$. parkeri developed a more robust humoral immune response.

The groups inoculated by the SC route (G3 and G4) exhibited higher antibody titers than the other groups (Table 1 and Figure 2). These results indicate that the $\mathrm{SC}$ route provided a greater stimulus to the immune system of the birds in this experiment. The animals in G3 exhibited significantly higher antibody titers than those in G1 (IM), G5 and G6 (both IP route) at $21 \mathrm{~d}$ PI (Figure 1d). Among all groups, G4 (SC) exhibited the highest anti- $R$. parkeri antibody titers, which were significantly different from those of G1 (IM), G5 and G6 (both IP) at 7d PI (Figure 1b). A statistically significant difference was observed between G4 (SC) and G1 (IM) and between G4 (SC) and G5 (IP) at $14 \mathrm{~d}$ PI (Figure 1c). A statistically significant difference was also observed between G1 and G2 (both IM), and G5 and G6 (both IP) at $21 \mathrm{~d}$ PI (Figure 1d). Valbuena et al. (2002) identified the site of infection as an important factor to determine the pathway and severity of rickettsial infection. In their natural life cycle, SFG rickettsias are inoculated in the hypodermis and subcutaneous tissue of the vertebrate host through the saliva of the arthropod host. Indeed, rickettsias with a low pathogenicity, such as $R$. parkeri, replicate preferentially at the vector inoculation site, which may develop skin lesions. In this study, the birds inoculated by the SC site (mimicking natural infection) demonstrated higher titers of anti-R. parkeri antibodies.

The route of infection can play an important role in early or late immune responses. Valbuena et al. (2002) asserted that if the infection follows the lymphatic endothelium route, it would lead to the infection of dendritic cells, followed by efficient antigen presentation and containment of the infection by an early adaptive immune response. This course of infection may have been demonstrated in G4 7d PI, since a number of birds in this group exhibited a higher magnitude immune response.

The reduction in antibody titers observed in most groups after 7 and/or $14 \mathrm{~d}$ PI (Figure 2) may indicate the inhibition of $R$. parkeri replication in experimentally infected chickens. Increased levels of circulating antigen are needed to maintain high levels of antibodies after $21 \mathrm{~d}$ PI. This was confirmed by Piranda et al. (2008), using dogs that were experimentally infected with $R$. rickettsia, which exhibited antibody titers that remained elevated until $180 \mathrm{~d}$ PI.

The antigen presentation system in birds is not as well known as that in mammals (WU; KAISER, 2011). However, dendritic cells participate in the immune response of birds (DEL CACHO et al., 2009). In domestic chickens, dendritic cells have been isolated from cecal tonsils, secondary lymphoid tissue, and diffuse lymphoid regions (BEFUS et al., 1980; HOSHI; MORI, 1973; OLAH; GLICK, 1979). The results of the present study are consistent with the participation of dendritic cells (especially $7 \mathrm{~d}$ PI) or other cells with phagocytic activity (WU; KAISER, 2011). In G1, the immune response was delayed, probably due to the shorter period of exposure to dendritic cells.

The absence of $R$. parkeri in the tissues might be explained by an inability of the inoculated rickettsia to replicate in the lungs and spleen of chickens. Furthermore, the rickettsiae could be present in these organs at levels that are not detectable by PCR, as has been suggested in previous studies (KATO et al., 2013; ORMSBEE et al., 1978).

The experimental animal model used in the present study, has a body temperature of around $42{ }^{\circ} \mathrm{C}$, which might influence the replication and spread of $R$. parkeri in animal tissues. $\mathrm{Li}$ and Walker (1992) showed that the ability of Rickettsia conorii to infect host cells was altered by increasing 
the temperature in cell culture. This finding could suggest that $R$. parkeri infection in birds may be limited by the elevated body temperature. However, more studies are required to confirm this hypothesis.

\section{Conclusions}

The results reported here demonstrated that domestic chickens challenged by $R$. parkeri seroconverted, with high titers of antibodies after 7 and $14 \mathrm{~d}$ PI. The highest specific antibody titers were dose-dependent and associated with administration of the inoculum by the SC via, simulating the natural route of transmission this rickettsia. In addition, it was not possible to detect the presence or replication of rickettsia in the spleen and lungs of the chickens studied.

\section{Acknowledgments}

The financial support from Conselho Nacional de Desenvolvimento Científico e Tecnológico (CNPq, National Counsel of Technological and Scientific Development), Fundação de Amparo à Pesquisa do Estado do Rio Grande do Sul (FAPEGS) and Coordenação de Aperfeiçoamento de Pessoal de Nível Superior (CAPES).

\section{References}

BEFUS, A. D.; JOHNSTON, N.; LESLIE, G. A.; BIENENSTOCK, J. Gut-associated lymphoid tissue in the chicken. I. Morphology, ontogeny and some functional characteristics of Peyer's patches. The Journal of Immunology, Bethesda, v. 125, n. 6, p. 2626-2632, 1980.

CONTI-DÍAZ, I. A.; MORAES-FILHO, J.; PACHECO, R. C.; LABRUNA, M. B. Serological evidence of Rickettsia parkeri as etiological agent of rickettsiosis in Uruguay. Revista do Instituto de Medicina Tropical de São Paulo, São Paulo, v. 51, n. 6, p. 337-339, 2009.

DEL CACHO, E.; GALLEGO, M.; LILLEHOJ, H. S.; LÓPEZ-BERNARD, F.; SÁNCHEZ-ACEDO, C. Avian follicular and interdigitating dendritic cells: isolation and morphologic, phenotypic, and functional analyses.
Veterinary Immunology and Immunopathology, Amherst, v. 129, n. 1-2, p. 66-75, 2009.

ELFVING, K.; OLSEN, B.; BERGSTRÖM, S.; WALDENSTRÖM, J.; LUNDKVIST, A.; SJÖSTEDT, A.; MEJLON, H.; NILSSON, K. Dissemination of spotted fever Rickettsiaagents in Europe by migrating birds. PloS One, San Francisco, v. 5, n. 1, p. 1-5, 2010.

GIMENEZ, D. F. Staining rickettsiae in yolk-sac cultures. Biotechnic \& Histochemistry, Baltimore, v. 39, n. 3, p. 135-140, 1964.

GRAHAM, R. I.; MAINWARING, M. C.; DU FEU, R. Detection of spotted fever group Rickettsiaspp. from bird ticks in the U.K. Medical and Veterinary Entomology, Malden, v. 24, n. 3, p. 340-343, 2010.

HILDEBRANDT, A.; FRANKE, J.; MEIER, F.; SACHSE, S.; DORN, W.; STRAUBE, E. The potential role of migratory birds in transmission cycles of Babesia spp., Anaplasma phagocytophilum, and Rickettsiaspp. Ticks and Tick-borne Diseases, Lippersdorf, v. 1, n. 2, p. 105-107, 2010.

HORTA, M. C.; SABATINI, G. S.; MORAES-FILHO, J.; OGRZEWALSKA, M.; CANAL, R. B.; PACHECO, R. C.; MARTINS, T. F.; MATUSHIMA, E. R.; LABRUNA, M. B. Experimental infection of the opossum Didelphis aurita by Rickettsia felis, Rickettsia belli, and Rickettsia parkeri and evaluation of the transmission of the infection to ticks Amblyomma cajennense and Amblyomma dubitatum. Vector-Borne and Zoonotic Diseases, New Rochelle, v. 10, n. 10, p. 959-967, 2010.

HORTA, M. C.; LABRUNA, M. B.; SANGIONI, L. A.; VIANNA, M. C.; GENNARI, S. M.; GALVÃO, M. A.; MAFRA, C. L.; VIDOTTO, O.; SCHUMAKER, T. T. S.; WALKER, D. H. Prevalence of antibodies to spotted fever group rickettsiae in humans and domestic animals in a Brazilian spotted fever-endemic area in the state of São Paulo, Brazil: serologic evidence for infection by Rickettsia rickettsiiand another spotted fever group Rickettsia. The American Journal of Tropical Medicine and Hygiene, Deerfield, v. 71, n. 1, p.93-97, 2004.

HOSHI, H.; MORI, T. Identification of the bursadependent and thymus-dependent areas in the tonsilla caecalis of chickens. The Journal of Experimental Medicine, New York, v. 111, n. 4, p. 309-322, 1973.

KATO, C. Y.; CHUNG, I. H.; ROBINSON, L. K.; AUSTIN, A. L.; DASCH, G. A.; MASSUNG, R. F. Assessment of real-time PCR assay for detection of Rickettsiaspp. and Rickettsia rickettsii in banked clinical samples. Journal of Clinical Microbiology, Washington, v. 51, n. 1, p. 314-317, 2013. 
LABRUNA, M. B.; WHITWORTH, T.; HORTA, M. C.; BOUYER, D. H.; MCBRIDE, J. W.; PINTER, A.; POPOV, V.; GENNARI, S. M.; WALKER, D. H. Rickettsiaspecies infecting Amblyomma cooperi ticks from an area in the state of Sao Paulo, Brazil, where Brazilian spotted fever is endemic. Journal of Clinical Microbiology, Washington, v. 42, n. 1, p. 90-98, 2004.

LI, H.; WALKER, D. H. Characterization of rickettsial attachment to host cells by flow cytometry. Infection and Immunity, Washington, v. 60, n. 5, p. 2030-2035, 1992.

LUGARINI, C.; MARTINS, T.F.; OGRZEWALSKA, M.; VASCONCELOS, N. C. T.; ELLIS, V. A.; OLIVEIRA, J. B.; PINTER, A.; LABRUNA, M. B.; SILVA, J. C. R. Rickettsial agentes in avian ixodid ticks in northeast Brazil. Ticks and Tick-borne Diseases, Lippersdorf, v. 6, n. 3, p. 364-375, 2015.

LUNDGREN, D. L.; THORPE, B. D.; HASKELL, C. D. Infectious diseases in wild animals in Utah. VI. Experimental infection of birds with Rickettsia rickettsii. Journal of Bacteriology, Washington, v. 91, n. 3, p. 963966, 1966.

NAVA, S.; ELSHENAWY, Y.; EREMEEVA, M. E.; SUMNER, J. W.; MASTROPAOLO, M.; PADDOCK, C. D. Rickettsia parkeri in Argentina. Emerging Infectious Diseases, Atlanta, v. 14, n. 12, p. 1894-1897, 2008.

OGRZEWALSKA, M.; UEZU, A.; LABRUNA, M. B. Ticks (Acari: Ixodidae) infesting wild birds in the eastern Amazon, northern Brazil, with notes on rickettsial infection in ticks. Parasitology Research, Düsseldorf, v. 106, n. 4, p. 809-816, 2010.

OLAH, I.; GLICK, B. Structure of the germinal centers in the chicken caecal tonsil: light and electron microscopic and autoradiographic studies. Poultry Science, Champaign, v. 58, n. 1, p. 195-210, 1979.

ORMSBEE, R.; PEACOCK, M.; GERLOFF, R.; TALLENT, G.; WIKE, D. Limits of rickettsial infectivity. Infection and Immunity, Washington, v. 19, n. 1, p. 239245, 1978.

PADDOCK, C. D.; SUMNER, J. W.; COMER, J. A.; ZAKI, S. R.; GOLDSMITH, C. S.; GODDARD, J.; MCLELlAN, S. L.; TAMMINGA, C. L.; OHL, C. A. Rickettsia parkeri: A newly recognized cause of spotted fever rickettsiosis in the United States. Clinical Infectious Diseases, Chicago, v. 38, n. 6, p. 805-811, 2004.

PHILIP, R. N.; CASPER, E. A. Serotypes of spotted fever group rickettsiae isolated from Dermacentor andersoni(Stiles) ticks in western Montana. The American Journal of Tropical Medicine and Hygiene, Deerfield, v. 30, n. 1, p. 230-238, 1981.
PIRANDA, E. M.; FACCINI, J. L.; PINTER, A.; SAITO, T. B.; PACHECO, R. C.; HAGIWARA, M. K.; LABRUNA, M. B. Experimental infection of dogs with a Brazilian strain of Rickettsia rickettsii: clinical and laboratory findings. Memórias do Instituto Oswaldo Cruz, Rio de Janeiro, v. 103, n. 7, p. 696-701, 2008.

REGNERY, R. L.; SPRUILL, C. L.; PLIKAYTIS, B. D. Genotypic identification of rickettsiae and estimation of intraspecies sequence divergence for portions of two rickettsial genes. Journal of Bacteriology, Washington, v. 173, n. 5, p. 1576-1589, 1991.

ROMER, Y.; SEIJO, A. C.; CRUDO, F.; NICHOLSON, W. L.; VARELA-STOKES, A.; LASH, R. R.; PADDOCK, C. D. Rickettsia parkeririckettsiosis, Argentina. Emerging Infectious Diseases, Atlanta, v. 17, n. 7, p. 1169-1173, 2011.

SANGIONI, L. A.; VOGEL, F. F. S.; CADORE, G. C.; HILGER, R. B.; TONIM, R.; PACHECO, R. C.; OGRZEWALSKA, M.; LABRUNA, M. B. Rickettsial infection in Cerro Largo, State of Rio Grande do Sul, Brazil. Arquivo Brasileiro de Medicina Veterinária e Zootecnia, Belo Horizonte, v. 63, n. 2, p. 511-514, 2011.

SILVA, N.; EREMEEVA, M. E.; ROZENTAL, T.; RIBEIRO, G. S.; PADDOCK, C. D.; RAMOS, E. A.; FAVACHO, A. R.; REIS, M. G.; DASCH, G. A.; DE LEMOS, E. R.; KO, A. I. Eschar-associated spotted fever rickettsiosis, Bahia, Brazil. Emerging Infectious Diseases, Atlanta, v. 17, n. 2, p. 275-278, 2011.

SILVEIRA, I.; PACHECO, R. C.; SZABÓ, M. P.; RAMOS, H. G.; LABRUNA, M. B. Rickettsia parkeri in Brazil. Emerging Infectious Diseases, Atlanta, v. 13, n. 7, p. 1111-1113, 2007.

SPOLIDORIO, M. G.; LABRUNA, M. B.; MANTOVANI,E.; BRANDAO,P.E.; RICHTZENHAIN, L. J.; YOSHINARI, N. H. Novel spotted fever group rickettsiosis, Brazil. Emerging Infectious Diseases, Atlanta, v. 16, n. 3, p. 521-523, 2010.

VALBUENA, G.; FENG, H. M.; WALKER, D. H. Mechanisms of immunity against rickettsiae. New perspectives and opportunities offered by unusual intracellular parasites. Microbes and Infection, Merced, v. 4, n. 6, p. 625-633, 2002.

VENZAL, J. M.; PORTILLO, A.; ESTRADA-PEÑA, A.; CASTRO, O.; CABRERA, P. A.; OTEO, J. A. Rickettsia parkeri in Amblyomma triste from Uruguay. Emerging Infectious Diseases, Atlanta, v. 10, n. 8, p. 1493-1495, 2004.

WU, Z.; KAISER, P. Antigen presenting cells in a nonmammalian model system, the chicken. Immunobiology, Leicester, v. 216, n. 11, p. 1177-1183, 2011. 
